\title{
KAJIAN FAKTOR PENARIK (PULL FACTOR) PENGHUNI BERTEMPAT TINGGAL DI KOMUNITAS BERPAGAR (GATED COMMUNITY) STUDI KASUS KECAMATAN MEDAN SELAYANG
}

\author{
Friendly C. R. Giawa ${ }^{(1)}$, Shanty Silitonga, ST.MT ${ }^{(2)}$, Raimundus Pakpahan, ST. MT ${ }^{(3)}$ \\ (1) Mahasiswa, Prodi Arsitektur, Fakultas Teknik, Universitas Katolik Santo Thomas Sumatera Utara \\ (2) Staff Pengajar, Prodi Arsitektur, Fakultas Teknik, Universitas Katolik Santo Thomas Sumatera Utara \\ Email: shanty.silitonga@gmail.com \\ (3) Staff Pengajar, Prodi Arsitektur, Fakultas Teknik, Universitas Katolik Santo Thomas Sumatera Utara \\ Email: pakpahanray@yahoo.co.id
}

\begin{abstract}
The growth of gated communities in District of Medan Selayang for 20 years is very rapid, the people today tend to choose to live in a closed community. The community considers that living in the closed and elite community is a matter of pride, even though it causes disconnection with the surrounding environment. This study aims to find out what is the pull factor of people living in gated communities, especially in Kecamatan Medan Selayang. The type of research used in the research are; Descriptive qualitative, then it is analyzed on a nominal scale and Likert Scale. This research concludes that the pull factor of residents residing in gated communities in Medan Selayang sub-district is a factor of Security, Access, Economy and Facilities, Privacy and Exclusivity.
\end{abstract}

Keywords : pull factor, gated community

\begin{abstract}
Abstrak
Pertumbuhan komunitas berpagar yang ada di Kecamatan Medan Selayang selama 20 tahun ini sangat pesat, masyarakat saat ini cenderung untuk memilih bertempat tinggal dalam suatu komunitas yang tertutup. Masyarakat menganggap bahwa jika tinggal pada kawasan elit merupakan kebanggaan tersendiri, walaupun hunian tersebut menyebabkan terputusnya hubungan mereka dengan lingkungan sekelilingnya.Penelitian ini bertujuan untuk mencari tahuapa yang menjadi faktor penarik (pull factor) masyarakat bertempat tinggal di komunitas berpagar (gated community) khususnya di Kecamatan Medan Selayang. Jenis penelitian yang digunakan dalam penelitian yaitu; penelitian Deskriptif kualitatif kemudian dianalisis dengan skala nominal dan Skala Likert.Penelitian ini menghasilkan kesimpulan bahwa faktor penarik (pull factor) penghuni bertempat tinggal di komunitas berpagar (gated community) di Kecamatan Medan Selayangadalah faktor Keamanan, Akses, Ekonomi dan Fasilitas, Privasi dan Ekseklusivitas.
\end{abstract}

Kata Kunci: pull factor, komunitas berpagar(gated community).

\section{Pendahuluan}

Komunitasberpagar(gatedcommunity)adalah kawasanpermukimandengan akses terbatas yang membuatruang publik menjadi privat. Aksesdikendalikanoleh pembatasfisik,dinding ataupagar, dan gerbangataupenjagapintu masuk.Komunitasberpagar mencakup pembangunanperumahanbarudan daerahper- mukimanlamayangdikelilingioleh barikadedan pagar. Seperti halnya yang terjadi di Kecamatan Medan Selayang pertumbuhan komunitas berpagar semakin meningkat, ini dapat dilihat selama 20 tahun ini pertumbuhan komunitas berpagar mencapai 69 perumahan yang tergolong komunitas berpagar khususnya di Kecamatan Medan Selayang. Terjadinya pertumbuhan komunitas berpagar di Kecamatan Medan Selayang ini dikarenakan kebanyakan masyarakat berpindah dan berkeinginan bertempat tinggal di komunitas berpagar yang suasananya aman dan privasi serta menganggap bahwa jika tinggal pada kawasan elit merupakan kebanggaan tersendiri, walaupun hunian tersebut menyebabkan terputusnya hubungan mereka dengan lingkungan sekelilingnya.Penulis beranggapan bahwa pertumbuhan komunitas berpagar di Kecamatan Medan Selayang tidak lepas dari pertumbuhan masyarakat itu sendiri, dimana masyarakat yang 
bertempat tinggal di dalam komunitas berpagar adalah masyarakat yang sebelumnya berhubungan atau masih berhubungan dengan perkotaan. Namun disisi lain ada juga pengaruh menjamurnya komunitas berpagar ini selain penghuni yaitu: seperti kebijakan pemerintah daerah maupun pusat yang memberikan akses perizinan kepada developer untuk membangun permukiman sebagai upaya pendukung dari program pemerintah yang bekerjasama dengan pihak swasta membangun perumahan dalam rangka kesejahteraan rakyat.Penelitian ini bertujuan untuk mengkaji faktor apa saja yang menjadi penarik bertempat tinggal di komunitas berpagar di Kecamatan Selayang.

\section{Latar Belakang Teori}

Faktor-faktor yang mengakibatkan orang memilih bertempat tinggal di dalam komunitas berpagar:

Pertama; merasa aman bertempat tinggal di komunitas berpagar.Sehingga rasa aman menjadi salah satu alasan utama masyarakat.Karena tingkat kejahatan yang semakin meningkat, sehingga muncul budaya rasa takut. Kadang juga karena keterpaksaan dilakukan karena berada di kawasan kota yang sangat rawan kriminalitas, sehingga mereka lebih memilih bertempat tinggal di tempat yang memiliki sistem keamanan khusus yang dapat menjadikan lingkungan perumahan aman, teratur dan dapat diprediksi. Kebanyakan masyarakat menganggap bahwa pagar identik dengan keamanan dan perasaan aman yang menjadi dambaan di lingkungan kota yang cenderung makin liar.

Kedua; Pencapaian keluar-masuk dalam area komunitas berpagar merupakan sebuah keputusan yang dipertimbangkan masyarakat serta beberapa alasan seperti ragam aktivitas anggota komunitas, Dari segi desain jalan, pola perumahan dengan jalan yang memanjang (menghubungan satu akses pintu keakses pintu lainnya) dianggap lebih baik.

Ketiga; keinginan untuk tinggal di kawasan elit berbenteng ini dianggap sebagai media imaji untuk menaikkan status sosial. Gaya hidup dan prestise yang sering terkait dengan perilaku dan kebiasaan manusia yang sering diidentikkan dengan kekayaan. Kebutuhan akan prestise dan stastus yang diperoleh serta gaya hidup yang seperti ini akan menimbulkan pola hidup modern.

Keempat, Masalah ekonomi menjadi persoalan bagi masyarakat, Karena fasilitas dan gaya hidup yang tidak bisa disediakan oleh pemerintah setempat mendorong migrasi ke komunitas berpagar yang mana telah disediakan berbagai fasilitas seperti area rekreasi, lapangan golf, dan interaksi sosial. Sehingga ketersediaan fasilitas dalam komunitas berpagar merupakan salah satu daya tarik bagi masyarakat.

Kelima; Para penghuni membutuhkan privasi yang tinggi dan terhindar dari gangguan aktivitas sosial yang dianggapnya tidak perlu karena menyita banyak tenaga dan waktu. Ruang publik dan privasi mereka telah dilindungi dinding atau pagar mereka sudah aman serta pintu masuk yang dikontrol untuk mencegah penetrasi oleh nonpenduduk (masyarakat yang tidak bertempat tinggal di dalam komunitas berpagar). Alasan lainnya adalah untuk menjaga teritori diri yang mereka miliki dan mempertahankannya dari hal-hal lain dari luar dirinya.

\section{Metode Penelitian}

Penelitian inimenggunakan metode kualitatif (Creswell,2008),yang bersifat deskriptif (Groat\&Wang, 2002). Deskriptif digunakan untuk memaparkan suatu gejala, peristiwa, atau kejadian yang sedang berlangsung. Penelitian ini memusatkan perhatian kepada masalah-masalah actual sebagaimana adanya pada saat penelitian berlangsung dan tidak ada perlakuan khusus.

\section{Teknik Pengumpulan Data}

Berikut ini rancangan penelitian yang berbasis pada metodologi penelitian deskriptif kualitatif yang akan dilakukan :

\section{Populasi Dan Sampel}

a. Populasi

Menurut Arikunto (Prosedur penelitian suatu pendekatan praktik-:130) Populasi adalah keseluruhan subjek penelitian. Arikunto (1996:18) juga menyatakan bahwa populasi adalah keseluruhan subjek penelitian, apabila seseorang ingin meneliti semua elemen yang ada dalam wilayah penelitiannya merupakan penelitian 
populasi.Populasi dalam penelitian ini adalah masyarakat Kecamatan Medan Selayang yang bertempat tinggal di komunitas berpagar.Komunitas berpagar pertama kalinya muncul di Kecamatan Medan Selayang mulai pada tahun 1995 sampai saat ini. jumlah komunitas berpagar dari tahun 1995 - 2015 di Kecamatan Medan Selayang mencapai 69 Perumahan dan ini yang menjadi populasi dalam penelitian ini.

b. Sampel

Menurut sugiyono 2013, sampel adalah bagian dari jumlah karakteristik yang dimiliki oleh populasi tersebut. Dalam hal ini batasan penelitian yang dijadikan sampel dengan mengelompokkan berdasarkan umur yaitu :

1) Tahun pertamakali munculnya komunitas berpagar di Kecamatan Medan Selayang sebagai awal pertumbuhan komunitas berpagar dalam hal ini Debang Taman Sari yang dibangun pada tahun 1995 dengan jumlah 242 Unit pada tahap I dan tahap ke II 146 unit dengan berbagai type rumah.

2) Pertengahan tahun perkembangan komunitas berpagar di Kecamatan Medan Selayang sebagai awal pertumbuhan komunitas berpagar dalam hal ini Classic 1 yang dibangun pada tahun 2004 dengan jumlah 102 Unit dengan 1 type.

3) Tahun terakhir perkembangan komunitas berpagar di Kecamatan Medan Selayang sebagai awal pertumbuhan komunitas berpagar dalam hal ini Grand Medaline yang dibangun pada tahun 2015 berjumlah 65 Unit dengan 2 model dan Type.

\section{Teknik Menentukan Jumlah Sampling}

Teknik sampling ini digunakan untuk menentukan jumlah sampel dari sejumlah populasi yang akan diteliti. Karena sampel sudah ditentukan dari atas, maka yang dicari jumlah responden dari 3 sampel komunitas berpagar di Kecamatan Medan Selayang.Makajumlah jumlah sampel (responden) yang akan diambil, dihitung berdasarkan rumus Slovin dalam Sudrajat (2002) sebagai berikut.

Jumlah sampel (responden) yang dipakai adalah jumlah penghuni dari tiga komunitas berpagar sebagai sampel sebanyak 1.875 jiwa. Data ini dapat dilihat dari jumlah jiwa sesuai data dari lapangan yaitu ;

Diketahui :

- Jumlah penghuni Debang Taman Sari $=1115$ orang

- Jumlah penghuni Classic $1=571$ orang

- Jumlah penghuni Grand Medaline $=189$ orang

$J \mathrm{lh}=1875$ Orang

$$
n=\frac{\mathrm{N}}{1+\left(\mathrm{N} \mathrm{x} \mathrm{e}^{2}\right)}
$$

Keterangan:

$\mathrm{n}$ = Ukuran sampel

$\mathrm{N}$ = Jumlah populasi

$\mathrm{e}^{2}=$ Persentase kesalahan pengambilan sampel yang masih diinginkan (5-10\%)

$n=\frac{1.875}{1+\left(1.875 \times 0.1^{2}\right)}$

$n=\frac{1.875}{1+\left(1.875 \times 0.1^{2}\right)}$

$n=\frac{1.875}{19.75}$

$$
=94.93 \text { (dibulatkan) } 95 \text { orang }
$$

\section{MetodePengumpulan Data}

Penelitian deskriptif ini bertujuan untuk mendapatkan faktor penarik penghuni bertempat tinggal di komunitas berpagar khususnya di Kecamatan Medan Selayang lewat hasil dari pengumpulan data berupa pengamatan lapangan,survey lapangan, studi banding,dan studi pustaka dan landasan teori. 
Skala pengukuran adalah seperangkat aturan yang diperlukan untuk mendapatkan data kuantitatif data dari pengukuran suatu variabel. Skala pengukuran dalam penelitian ini dengan menggunakan 2 skala yaitu skala Nominal, dan Skala Likert.

Dalam penelitian ini kuesioner merupakan alat utama yang digunakan untuk mencapai tujuan dalam penelitian ini. Format kuesioner harus dirancang dengan baik agar terpenuhi syarat perhitungan sesuai dengan tujuan penelitian.

Teknik analisis data yang digunakan dalam penelitian ini adalah dengan teknik Skala Likert sehingga hasilnya dapat dilihat dalam suatu laporan ilmiah. Menurut Sugiyono(2012:134), Skala likertdigunakan untukmengukur sikap,pendapatdanpersepsiseseorang atausekelompokorangtentangfenomenasosial.

\section{Hasil Analisa}

Berdasarkan hasil analis penelitian dari tiga sampel komunitas berpagar di Kecamatan Medan Selayang dengan data kuisioner yang dimiliki yaitu: Pada perumahan Debang Taman Sari sebanyak 43 responden, Perumahan Classic 1 sebanyak 21 responden, Petumahan Garnd medaline sebanyak 13 responden. Sehinga jumlah responden mencapai 77 reseponden dengan 34 pertanyaan mengenai kajian faktor penarik (pull factor) penghuni bertempat tinggal di komunitas berpagar (gated community) di Kecamatan Medan Selayang dapat disimpulkan bahwa faktor penarik (pull factor) penghuni yang paling berpengaruh adalah :

\section{1) Perumahan Debang Taman Sari}

a. Faktor keamanan

faktor keamanan yang paling utama yang menjadi daya tarik penghuni bertempat tinggal dikomunitas berpagar di Perumahan Debang Taman Sari, seperti; Rasa takut akan kejahatan dan tingkat kriminal didalam komunitas berpagar berkurang, Adanya Satpam yang dapat mengontrol keamanan dalam komunitas berpagar.

Adapun yang tidak menjadi faktor penarik (pull factor) penghuni bertempat tinggal dikomunitas berpagar (gated community)di Perumahan Debang Taman Sari berdasarkan teori yaitu; Dapat menimbulkan rasa tenang dan aman dalam komunitas berpagar.

b. Akses

Akses menjadi faktor yang kedua bagi penghuni untuk bertempat tinggal dikomunitas berpagar di Perumahan Debang Taman Sari, seperti; Tingkat kemacetan masuk dikomunitas berpagar berkurang,penyediaan komunitas berpagar dekat dengan tempat kerja, penyediaan garasi/carport disetiap unit rumah, Luas jalan dalam komunitas berpagar cukup untuk dilalui, memiliki(keberadaan) pintu gerbang yang cukup jelas dan tersedianya jalur pejalan kaki yang baik dikomunitas berpagar.

c. Faktor Ekonomi dan Fasilitas

faktor ekonomi dan fasilitas menjadi faktor ketiga penghuni bertempat tinggal dikomunitas berpagar di Perumahan Debang Taman Sari, seperti; Penggunaan jaringan Listrik yang secara umum dari PLN dan PDAM, harga yang sangat terjangkau murah, ketersediaannya taman bermain serta bunga dan cicilannya yang cukup terjangkau.

Adapun yang tidak menjadi faktor penarik (pull factor) penghuni bertempat tinggal dikomunitas berpagar (gated community) di Perumahan Debang Taman Sari berdasarkan teori, seperti; penyediaan lampu jalan, ketersediaan kolam renang dan pembelian rumah secara kredit dalam komunitas berpagar.

d. Privasi

faktor privasi menjadi faktor keempat penghuni bertempat tinggal dikomunitas berpagar di Perumahan Debang Taman Sari, seperti; dapat terkontrol dengan adanya batasan-batasan tertentu (pagar) serta privasi dan teritori dikomunitas berpagar dapat terjaga dari masyarakat lainnya.

Adapun yang tidak menjadi faktor penarik (pull factor) penghuni bertempat tinggal dikomunitas berpagar (gated community) di Perumahan Debang Taman Sari berdasarkan teori, seperti; penyediaan lampu jalan, ketersediaan kolam renang dan pembelian rumah secara kredit dalam komunitas berpagar.

e. Ekseklusivitas

Ekseklusivitas menjadi faktor terakhir para penghuni bertempat tinggal dikomunitas berpagar di Perumahan Debang Taman Sari, seperti; gaya dan bentuk arsitektur dikomunitas berpagar itu cukup menarik. 
Adapun yang tidak menjadi faktor penarik (pull factor) penghuni bertempat tinggal dikomunitas berpagar (gated community) di Perumahan Debang Taman Sari berdasarkan teori, seperti; gaya hidup untuk tinggal diperumahan saat ini lagi ngetrend, kemewahan bangunan, karena sebagian rekan kerja tinggal dikomunitas berpagar, merasa bangga serta kewibawaan yang dapat terjamin dalam komunitas berpagar

\section{2) Perumahan Classic 1}

Pada Perumahan Classic 1 faktor-faktor yang mempengaruhi responden membeli ruma adalah Keamanan, Akses, Ekonomi dan Fasilitas, Privasi dan faktor terkecil yang mempengaruhi yaitu Ekseklusivitas.

\section{3) Perumahan Grand Medaline}

Sementara pada Perumahan Grand Medaline faktor-faktor yang mempengaruhi responden membeli rumah yaitu faktor Keamanan, Akses, Ekonomi dan Fasilitas, Privasi dan terakhir fakktor Ekseklusivitas.

Tabel 1. Faktor Penarik (Pull Factor) Penghuni Bertempat Tinggal Di Komunitas Berpagar (Gated Community) Di Kecamatan Medan

\begin{tabular}{|l|l|}
\hline \multicolumn{1}{|c|}{ Faktor } & \multicolumn{1}{c|}{ Pertimbangan } \\
\hline Aman & $\begin{array}{l}\text { - Lingkungan yang jauh dari kejahatan yang ditimbulkan oleh masyarakat sekitar } \\
\text { - Menyediakan sistem keamanan yang cukup ketat, seperti; satpam, tembok pagar } \\
\text { yang tinggi }\end{array}$ \\
\hline Akses & $\begin{array}{l}\text { - Akses yang bisa dijangkau dari berbagai tujuan, seperti; dekat dengan tempat kerja, } \\
\text { sekolah-sekolah dan tempat komersil lainnya } \\
\text { - Setiap rumah } \\
\text { - menyediakan garasi/cartport } \\
\text { - Luas jalan yang secukupnya } \\
\text { - Dalam komunitas harus disediakan pedestrian (jalur pejalan kaki) } \\
\text { - Memiliki pintu gerbang yang cukup jelas } \\
\text { - Lingkuan dapat dikontrol dengan cepat }\end{array}$ \\
\hline Ekonomi dan fasilitas & $\begin{array}{l}\text { - Penyediaan fasilitas yang secara umum digunakan masyarakat, seperti; jarinagn } \\
\text { Listrik, Air, taman bermain dan RTH }\end{array}$ \\
\hline Eksklusivitas & - Harga dan cicilannya yang bisa dijangkau oleh masyarakat \\
\hline
\end{tabular}

Sumber: Olahan Pribadi

\section{Kesimpulan}

Penelitian ini menemukan bahwa faktor penarik penghuni memilih tinggal disebuah komunitas berpagar sebagian besar adalah faktor pertama adalah faktor keamanan, kedua faktor akses, dan ketiga adalah faktor fasilitas/ekonomi.Bagi team pengembang, perencana perumahan dan pihak yang berkaitan dengan pengembang perumahan di Kecamatan Medan Selayang, sebaiknya memperhatikan faktor-faktor penarik tersebut dan memasukkannya kedalam perencanaan sehingga dapat menarik lebih banyak konsumen mereka.

\section{Daftar Pustaka}

Blakely, Edward J; Snyder, Mary Gail, 1997, Fortress America: Gated Communities in the United States, Brookings Institution

Gülümser A A, 2005, A New Trend in Urbanization: Gated Communities in Istanbul unpublishedMaster Thesis Supervised by Assoc. Prof. Dr. Tüzin Baycan Levent, Institute of Technologyand Science, Istanbul Technical University

Taylor, Bogdan, 2001, Metodologi penelitian kualitatif, PT.Rosda Suprapto, Jakarta 